\title{
The relationship between thyroid function and ovarian reserve: a prospective cross- sectional study
}

\author{
Roya Kabodmehri ${ }^{1}$, Seyedeh Hajar Sharami ${ }^{1}$, Ziba Zahiri Sorouri ${ }^{1}{ }^{12}$, Nasrin Ghanami Gashti ${ }^{1}$, Forozan Milani ${ }^{\text {* }}$, \\ Zeinab Chaypaz ${ }^{1}$ and Maryam Ghalandari ${ }^{3}$
}

\begin{abstract}
Background: Thyroid dysfunction can affect fertility and miscarriage risk by affecting the process of follicular growth, embryo development, implantation, and placental formation. It has been suggested that thyroid disorders are associated with ovarian reserve by affecting the follicular process. The aim of the present study was to investigate the relationship between thyroid hormone levels and ovarian reserve.

Methods: Three hundred fourteen women with infertility due to various etiologies were enrolled in this study (172 individuals with Anti-Mullerian hormone (AMH) level $\geq 1.1 \mathrm{ng} / \mathrm{ml}$ and 142 individuals with $A M H<1.1 \mathrm{ng} / \mathrm{ml}$ ). Serum levels of follicle-stimulating hormone (FSH), estradiol (E2) on day 2-4 of menstrual cycles, AMH, Thyroid-stimulating hormone (TSH), and thyroxine (free T4) were evaluated.

Results: In participants with age over 35 years, median TSH level in women with $\mathrm{AMH}<1.1 \mathrm{ng} / \mathrm{ml}$ was significantly higher than those with $A M H \geq 1.1 \mathrm{ng} / \mathrm{ml}(P$-value $=0.037)$. There was no significant difference in body mass index (BMI) in patients with age older than 35 years and younger than 35 years sub-groups based on AMH level $(P$-value $=0.102$, and $P$-value $=0.909$ respectively). With one unit increase in TSH level, the odds of having $\mathrm{AMH}<1.1 \mathrm{ng} / \mathrm{ml}$ increases by 1.25 times or by $25 \%$ ( $P$-value $=0.017$ ). Receiver operator characteristic $(\mathrm{ROC})$ curve analysis showed a TSH cut-off point of $1.465 \mathrm{mIU} / \mathrm{L}$ in participants over 35 years in identifying decreased AMH level.
\end{abstract}

Conclusion: Our study supports the relationship between TSH level and ovarian reserve so that with an increase in TSH from a certain level is associated with a decrease in ovarian function.

Keywords: Thyroid dysfunction, ovarian reserve, TSH, AMH

\section{Background}

Decreased ovarian reserve and subsequent reduction in the quantity and quality of oocytes is a process that depends on age. However, this phenomenon can occur at any age. In younger patients, it is mostly idiopathic but there are other causes such as ovarian surgery,

\footnotetext{
*Correspondence: forozanmilani@yahoo.com

${ }^{1}$ Reproductive Health Research Center, Department of Obstetrics \& Gynecology, Al-Zahra Hospital, School of Medicine, Guilan University of Medical Sciences, Namjoo Street, P.O.Box: 4144654839, Rasht, Iran

Full list of author information is available at the end of the article
}

endometriosis, and chemo-radiotherapy in reproductive age. Anti-Mullerian hormone (AMH) is a glycoprotein produced from granulosa cells of follicles, sized between of 5 to $8 \mathrm{~mm}$ [1], and is a good biomarker for ovarian reserve. Its level is constant throughout the menstrual cycle and has a high specificity for detecting the inadequate ovarian response [2].

One of the factors affecting the functional reserve of the ovary is thyroid disorders. Thyroid diseases are one of the most common endocrine problems in reproductive age and may cause menstrual and ovulation disorders original author(s) and the source, provide a link to the Creative Commons licence, and indicate if changes were made. The images or other third party material in this article are included in the article's Creative Commons licence, unless indicated otherwise in a credit line to the material. If material is not included in the article's Creative Commons licence and your intended use is not permitted by statutory regulation or exceeds the permitted use, you will need to obtain permission directly from the copyright holder. To view a copy of this licence, visit http://creativecommons.org/licenses/by/4.0/. The Creative Commons Public Domain Dedication waiver (http://creativeco mmons.org/publicdomain/zero/1.0/) applies to the data made available in this article, unless otherwise stated in a credit line to the data. 
and infertility. The prevalence of subclinical and clinical hypothyroidism in women of reproductive age is 4-10 and 0.1-2\%, respectively [3]. The exact mechanism of the effect of thyroid disorders on menstruation and infertility is not precisely understood. Oocytes are surrounded by granulosa cells that are evolving as vital support for oocytes. Studies show that different cells in the ovary, including oocytes, granulosa cells, and epithelium express receptors of thyroid hormone. TSH has a synergistic effect with follicle stimulating hormone (FSH) in promoting the proliferation of granulosa cells [4]. On the other hand, studies have shown that thyroid hormones regulate FSH stimulation in follicles and prevent their apoptosis [5]. In the process of folliculogenesis, thyroid hormones bound to thyroid-binding globulin (TBG) increases with increasing serum estrogen levels, and the result of these phenomena is a decrease in free thyroxin and an increase in TSH level [6]. Thyroid hormone is also found in follicular fluid. It plays an important role in the process of follicle development [5] and its dysregulation may impair follicular development.

Thyroid hormone also plays an important role in the process of implantation and early development of the fetus through its effect on the endometrium and placenta, which can be used to regulate the invasion of the extra villus trophoblast by affecting the matrix metalloproteinase $[7,8]$. The expression of thyroid hormone receptors in the ovary and endometrium and its important role in endometrial receptivity, implantation window, placenta, and embryonic tissues has shown [4]. Studies examining the relationship between thyroid hormone level and ovarian reserve have shown conflicting results $[9,10]$. A number of studies support the association between high serum TSH level and decreased ovarian reserve; also, in euthyroid patients, TSH below $3 \mathrm{mIU} / \mathrm{ml}$ has been shown to be associated with better ovarian reserves $[11,12]$. On the other hand, this association has not been confirmed by other studies [13]. With increasing age, both ovarian reserve decreases, and thyroid disorders increase, therefor it is possible that there is an association between these two conditions. The aim of the present study was to investigate the relationship between thyroid hormones levels and ovarian reserve.

\section{Methods}

The present study is a prospective cross-sectional study that was conducted between 2019 and 2020 in AlZahra Hospital after obtaining approval from the Ethics Committee of Guilan University of Medical Sciences (Approval ID: IR.GUMS.REC.1399.541). A total of 314 women with infertility due to various causes (172 individuals with $A M H \geq 1.1 \mathrm{ng} / \mathrm{ml}$ and 142 individuals with $\mathrm{AMH}<1.1 \mathrm{ng} / \mathrm{ml}$ ) were included in the study. All women with infertility (not being able to get pregnant after 1 year or longer of unprotected sex) referred to the infertility clinic of Al-Zahra hospital, Rasht, Iran were included in the study. Exclusion criteria were any iatrogenic cause for decreased ovarian reserve such as ovarian surgery, radiotherapy and chemotherapy, endometriosis, history of known thyroid disorders, levothyroxine users, polycystic ovarian syndrome (PCOS), and patients who declined to participate in the study. Informed consent was obtained from all patients before enrollment. All participants had normal serum prolactin levels. The levels of FSH and estradiol (E2) on days 2-4 of the menstrual cycle (Siemens Immulite 2000 xpi Immunoassay System, Germany), AMH (Immunotech Beckman coulter ELISA kit, USA), TSH, and free T4 (Architect Abbott i 2000 SR, USA) were measured. The researcher-made checklist included demographic (age, BMI) and hormonal levels (FSH, luteinizing hormone (LH), AMH, TSH, Free T4, and E2) were recorded. The manufacturer's reference ranges were $0.45-4.5 \mathrm{mIU} / \mathrm{L}$ for TSH, and $12-22 \mathrm{pmol} / \mathrm{L}$ for free T4. Subclinical hypothyroidism was defined as $\mathrm{TSH}>4.5 \mathrm{mIU} / \mathrm{mL}$ with the free $\mathrm{T} 4$ concentration within the reference range. Patients with $\mathrm{TSH}>4.5 \mathrm{mIU} / \mathrm{L}$ and low free $\mathrm{T} 4$ were considered as affected by clinical hypothyroidism.

\section{Statistical analysis}

The data were analyzed by using the IBM SPSS software (v 21.0. Armonk, NY, USA). The normal distribution of quantitative variables was assessed using the Kolmogorov-Smirnov test. The median and the interquartile range (IQR) were used for analyzing quantitative variables, and numbers and percentages were used for qualitative variables. The relationship between clinical hypothyroidism and subclinical hypothyroidism variables in both $\mathrm{AMH}$ groups was analyzed using the Chi-square test and Fisher's exact test. Comparison of hormonal variables in the two groups of participants in the study $(\mathrm{AMH} \geq 1.1 \mathrm{ng} / \mathrm{ml}$ and $\mathrm{AMH}<1.1 \mathrm{ng} / \mathrm{ml}$ ) was analyzed using Mann-Whitney $\mathrm{U}$ test. The relationship between AMH and Free T4, FSH, TSH, and E2 was analyzed using the partial correlation test. Then, variables that had a $P$-value of less than 0.2 in the partial correlation test were selected and were analyzed by multiple logistic regression analysis. In addition, we used the receiver operator characteristic (ROC) curve to estimate the cut-off point of TSH in identifying decreased AMH level. The statistical significance level was considered at $P$-value $<0.05$.

\section{Results}

A total of 314 women with infertility due to various causes (172 individuals with $\mathrm{AMH} \geq 1.1 \mathrm{ng} / \mathrm{ml}$ and 142 individuals with $\mathrm{AMH}>1.1 \mathrm{ng} / \mathrm{ml}$ ) were enrolled in this study. 
Mean age of participants was $36.66 \pm 6.12$ years. They were divided into two groups: patients with age 35 years or older and younger than 35 years. There was no significant difference in BMI in patients with age older than 35 years and younger than 35 years sub-groups based on AMH level $(P$-value $=0.102$, and $P$-value $=0.909$ respectively) (Table 1 ). The number of participants younger than 35 years was 124 (49.39\%) while the number of participants aged 35 years or older was 190 (51.60\%). Seventy percent of individuals aged 35 years or over and $19.4 \%$ of individuals younger than 35 years had AMH $<1.1 \mathrm{ng} / \mathrm{ml}$ $(P$-value $=0.001)$. Participants were evaluated for TSH, Free T4, FSH, E2 variables in each age group (Table 1). In participants with age over 35 years, median TSH level in women with $\mathrm{AMH}<1.1 \mathrm{ng} / \mathrm{ml}$ was significantly higher than those with AMH $\geq 1.1 \mathrm{ng} / \mathrm{ml}(P$-value $=0.037)$. Also, FSH level was significantly higher in individuals with $\mathrm{AMH}<1.1 \mathrm{ng} / \mathrm{ml}$ as compared to those with $\mathrm{AMH}$ $\geq 1.1 \mathrm{ng} / \mathrm{ml}$ in both the age groups $(P$-value $=0.001)$. Participants with $\mathrm{AMH}<1.1 \mathrm{ng} / \mathrm{ml}$ and those with $\mathrm{AMH}$ $\geq 1.1 \mathrm{ng} / \mathrm{ml}$ had similar levels of E2 and Free T4 in both age groups $(p>0.05)$ (Table 1$)$.

Results showed that despite the higher frequency of clinical hypothyroidism in the group with $\mathrm{AMH}<1.1 \mathrm{ng} /$ $\mathrm{ml}$ in both age groups, this difference was not statistically significant ( $P$-value $>0.05)$ (Table 1$)$. The partial correlation test was used to examine the relationship between $\mathrm{AMH}$, and Free T4, FSH, TSH, and E2 variables in the whole cohort and the two sub-groups $(\mathrm{AMH} \geq 1.1 \mathrm{ng} /$ $\mathrm{ml}$ and $\mathrm{AMH}<1.1 \mathrm{ng} / \mathrm{ml}$ ) controlling and eliminating the effect of age (Table 2). Results showed significant correlation between AMH and FSH in the both groups with
$\mathrm{AMH}<1.1 \mathrm{ng} / \mathrm{ml}$ and $\mathrm{AMH} \geq 1.1 \mathrm{ng} / \mathrm{ml}$. It indicates that if age is under control and all patients are the same age, FSH is inversely related to AMH in both AMH groups. Also, the partial correlation coefficient's between TSH and $\mathrm{FSH}$ in the group with $\mathrm{AMH} \geq 1.1 \mathrm{ng} / \mathrm{ml}$ and group with $\mathrm{AMH}<1.1 \mathrm{ng} / \mathrm{ml}$ shows that with age control there is a significant positive relationship between TSH and FSH in both AMH groups $(P$-value $=0.001)$ (Table 2$)$.

In multivariate logistic regression, TSH and age variables were significantly associated with low AMH, so that with one unit increase in TSH level, the odds of having $\mathrm{AMH}<1.1 \mathrm{ng} / \mathrm{ml}$ increases by 1.25 times or by $25 \%$ $(P$-value $=0.017)$ (Table 3$)$. Also, with an increase of 1 year in the age of patients, the odds of low AMH under the same conditions of variables increases by 1.296 times or $29.6 \%(P$-value $<0.001)$ (Table 3$)$. ROC curve analysis showed that TSH cut-off point of $1.465 \mathrm{mIU} / \mathrm{L}$ in participants over 35 years had $80.5 \%$ sensitivity, $38.6 \%$ specificity, and area under curve (AUC) $=0.596$ in identifying decreased AMH level.

\section{Discussion}

Both thyroid disorders and decreased ovarian reserve increase with aging. Autoimmune thyroid disorders have also been reported in 10 to $30 \%$ of patients with ovarian failure, suggesting thyroid disorders are associated with ovarian reserve $[14,15]$. In the present study, we examined the relationship between TSH and free T4 levels and markers of ovarian reserve, including AMH, E2, and FSH measured on the second day of the menstrual cycle. Seventy percent of the participants aged 35 years or older and $19.4 \%$ of the participants under the age of 35 years

Table 1 Clinical characteristics and hormones level in the two sub-groups of participants based on Anti-Mullerian hormone (AMH) levels.

\begin{tabular}{|c|c|c|c|c|c|c|c|}
\hline & & \multicolumn{3}{|l|}{ Age $\leq 35$ years } & \multicolumn{3}{|l|}{ Age $>35$ years } \\
\hline & & $\begin{array}{l}\mathrm{AMH}<1.1 \mathrm{ng} / \mathrm{ml} \\
\text { Median (IQR) }\end{array}$ & $\begin{array}{l}\mathrm{AMH} \geq 1.1 \mathrm{ng} / \mathrm{ml} \\
\text { Median (IQR) }\end{array}$ & $P$-value & $\begin{array}{l}\text { AMH }<1.1 \mathrm{ng} / \mathrm{ml} \\
\text { Median (IQR) }\end{array}$ & $\begin{array}{l}\mathrm{AMH} \geq 1.1 \mathrm{ng} / \mathrm{ml} \\
\text { Median (IQR) }\end{array}$ & ${ }^{*} P$-value \\
\hline BMI & & $26.6(24.96-29.2)$ & $27.0(24.50-29.77)$ & 0.909 & $27.6(25.5-30.4)$ & $28.4(26.68-31.32)$ & 0.102 \\
\hline \multirow[t]{3}{*}{ Clinical hypothyroidism } & yes & $2(66.7 \%)$ & $1(33.3 \%)$ & 0.096 & $6(100 \%)$ & 0 & 0.181 \\
\hline & no & $22(18.2 \%)$ & $99(81.8 \%)$ & & 127 (69\%) & $57(31 \%)$ & \\
\hline & total & $24(19.4 \%)$ & $100(80.6 \%)$ & & $133(70 \%)$ & $57(30 \%)$ & \\
\hline \multirow[t]{3}{*}{ Subclinical hypothyroidism } & yes & $2(28.6 \%)$ & $5(71.4 \%)$ & 0.525 & $15(83.3 \%)$ & $3(16.7 \%)$ & 0.194 \\
\hline & no & $22(18.8 \%)$ & $95(81.2 \%)$ & & $118(68.6 \%)$ & $54(31.4 \%)$ & \\
\hline & total & $24(19.4 \%)$ & $100(80.6 \%)$ & & $133(70 \%)$ & $57(30 \%)$ & \\
\hline TSH (mIU/L) & & $1.97(1.22-3.69)$ & $2.1(1.46-3.2)$ & 0.09 & $2.3(1.3-3.5)$ & $1.8(1.8-3.25)$ & 0.03 \\
\hline Free T4 (ng/dl) & & $8.55(6.75-11.42)$ & $8.77(7.51-10.15)$ & 0.98 & $8.5(6.5-9.8)$ & $8.83(7.8-10.1)$ & 0.05 \\
\hline FSH (IU/L) & & $9.95(7.92-17.55)$ & $5.5(4.1-6.8)$ & 0.0001 & $8.7(5.85-11.85)$ & $6.5(4.75-7.8)$ & 0.0001 \\
\hline E2 $(p g / m l)$ & & $39.5(26.67-70.45)$ & $48(37.2-68.15)$ & 0.12 & $57.1(33-81.15)$ & $49(35.6-68.7)$ & 0.29 \\
\hline
\end{tabular}

*Mann-Whitney $\mathrm{U}$ test

AMH Anti-Mullerian hormone, IQR Interquartile range, FSH Follicle-stimulating hormone, E2 Estradiol, TSH Thyroid stimulating hormone, Free T4 Thyroxine 
Table 2 The relationship between AMH and Free T4, FSH, TSH, E2 variables in the two sub-groups of participants based on AMH levels.

\begin{tabular}{|c|c|c|c|c|c|c|}
\hline Variables & & AMH & FSH & E2 & TSH & FreeT4 \\
\hline \multirow[t]{5}{*}{ All participants } & $\mathrm{AMH}$ & 1 & & & & \\
\hline & $\mathrm{FSH}$ & $-0.140^{*}$ & 1 & & & \\
\hline & E2 & -0.06 & -0.061 & 1 & & \\
\hline & TSH & -0.079 & $0.363^{* *}$ & -0.022 & 1 & \\
\hline & Free T4 & -0.009 & -0.018 & 0.006 & -0.003 & 1 \\
\hline \multirow[t]{5}{*}{$\mathrm{AMH}<1.1 \mathrm{ng} / \mathrm{ml}$} & $\mathrm{AMH}$ & 1 & & & & \\
\hline & FSH & $-0.326^{* *}$ & 1 & & & \\
\hline & E2 & -0.009 & -0.102 & 1 & & \\
\hline & $\mathrm{TSH}$ & -0.01 & $0.394^{* *}$ & -0.06 & 1 & \\
\hline & Free T4 & -0.092 & -0.015 & -0.026 & 0.011 & 1 \\
\hline \multirow[t]{5}{*}{$\mathrm{AMH} \geq 1.1 \mathrm{ng} / \mathrm{ml}$} & $\mathrm{AMH}$ & 1 & & & & \\
\hline & FSH & -0.108 & 1 & & & \\
\hline & E2 & -0.054 & -0.032 & 1 & & \\
\hline & TSH & -0.051 & 0.077 & 0.019 & 1 & \\
\hline & Free T4 & 0.044 & -0.155 & 0.137 & -0.077 & 1 \\
\hline
\end{tabular}

Partial correlation test, ${ }^{*} P$-value $<0.05 * * P$-value $<0.001$

FSH Follicle-stimulating hormone (IU/L), AMH Anti-Mullerian hormone (ng/ml), E2 Estradiol (pg/ml), TSH Thyroid stimulating hormone (mIU/ml)

Table 3 Relative impact of demographic and clinical variables on ovarian reserve on regression model (backward model).

\begin{tabular}{|c|c|c|c|c|c|c|}
\hline \multirow{2}{*}{$\begin{array}{l}\text { Factors affecting } \\
\text { AMH }\end{array}$} & \multirow{2}{*}{$\begin{array}{l}\text { Regression } \\
\text { coefficient's }\end{array}$} & \multirow[t]{2}{*}{ Standard error } & \multirow{2}{*}{$\begin{array}{l}\text { (Adjusted Odd } \\
\text { Ratios) }\end{array}$} & \multicolumn{2}{|c|}{ Confidence Interval 95\% } & \multirow[t]{2}{*}{$P$-value } \\
\hline & & & & Lower limit & Upper limit & \\
\hline TSH & 0.223 & 0.093 & 1.250 & 1.500 & 1.041 & 0.017 \\
\hline Age & 0.259 & 0.030 & 1.296 & 1.375 & 1.220 & 0.0001 \\
\hline Constant & -10.126 & 1.195 & 0.0001 & & & 0.0001 \\
\hline
\end{tabular}

Multivariate logistic regression

had AMH $<1.1 \mathrm{ng} / \mathrm{ml}(P$-value $<0.001)$. This finding is in line with other studies showing that aging is associated with a decrease in the quality and quantity of ovarian function [16-19]. It has been reported that ovarian reserve depletion and its acceleration occur at the age of 37.5 years [20]. Surprisingly, $19.4 \%$ of women aged less than 35 years in our study had AMH level $<1.1 \mathrm{ng} / \mathrm{ml}$. This may be due to the selection of participants among infertile women. The present study showed higher FSH levels in participants with $\mathrm{AMH}<1.1 \mathrm{ng} / \mathrm{ml}$ in both age groups $(P$-value $=0.001)$. This result is consistent with other studies that showed a negative relationship between $\mathrm{AMH}$ and FSH, and it has been suggested that reduced ovarian function causes changes in both quantity and quality of ovarian factors (inhibin) and FSH is increased through the feedback system [21]. Our results demonstrated that, in participants aged 35 years or older median TSH was higher in participants with $\mathrm{AMH}<1.1 \mathrm{ng} /$ $\mathrm{ml}$ as compared to those with $\mathrm{AMH} \geq 1.1 \mathrm{ng} / \mathrm{ml}$ $(P$-value $=0.037)$. In contrast, in younger participants below the age of 35 years, we were unable to demonstrate significantly different TSH level between the participants with $\mathrm{AMH}<1.1 \mathrm{ng} / \mathrm{ml}$ and those with $\mathrm{AMH} \geq 1.1 \mathrm{ng} /$ $\mathrm{ml}(P$-value $=0.09)$. Our findings were based on a single TSH measurement, and the failure to achieve statistically significant results on the relationship between TSH and ovarian reserve in younger participants can be due to physiological variability of TSH concentrations. According to our multiple logistic regression analysis (backward method), only the TSH and age remained significantly associated with $\mathrm{AMH}$, so that with an increase of one unit in TSH values, the odds of patients being in the low $\mathrm{AMH}$ group at the same age increases 1.25 times or by $25 \%(P$-value $=.017)$. Also, with an increase of one unit in the age of patients, the chance of patients being in the low AMH group under the same conditions of TSH level increases 1.296 times or increases by $29.6 \%$ ( $P$-value $<.001)$. Our ROC curve analysis showed that a TSH cutoff point of $1.465 \mathrm{mIU} / \mathrm{L}$ in participants over 35 years predicted decreased AMH level with $80.5 \%$ sensitivity, $38.6 \%$ specificity, and AUC $=0.596$. 
Our finding contradicts a number of other studies $[9,10,15]$. In 2015 a cross-sectional analytical study [22] that was conducted in a large cohort population, all three groups of patients with normal, low, and high ovarian response were included. They found no relationship between thyroid hormone level and AMH level and their results were replicated by several other studies [13, 22-24]. However, most of these have been retrospective studies. Several studies have supported the relationship between TSH and AMH levels and have suggested that even in euthyroid patients, serum TSH levels less than $3 \mathrm{mIU} / \mathrm{ml}$ are associated with better ovarian function and if TSH is higher than this cut-off point, they recommended levothyroxine treatment $[11,25]$. On the contrary, in Kuroda et al. (2018) study [26], treatment with levothyroxine failed to change ovarian reserve in clinical and subclinical hypothyroidism even though AMH level was significantly increased in patients with Hashimoto thyroiditis. Michalakis et al. (2011) have shown an association between TSH level and ovarian reserve, and in $18 \%$ of patients with low ovarian reserve, TSH levels were higher than $4 \mu \mathrm{IU} / \mathrm{mL}$ [9].

The strengths of our study include the prospective study design, the ability to select patients correctly, performing biochemical tests in a single laboratory and the assessment of several ovarian reserve markers. Also, we adjusted several factors that may affect ovarian reserve. Limitations of our study include the inability to evaluate anti-thyroid antibodies and the small sample size. However, it has been previously demonstrated that even after adjustment for thyroid autoimmunity and age, TSH $<3.0 \mu \mathrm{IU} / \mathrm{mL}$ in euthyroid patients with infertility have significantly higher AMH level than as compared to those with $\mathrm{TSH} \geq 3.0 \mu \mathrm{IU} / \mathrm{mL} 14$ [11]. Another limitation of the study was the selection of participants from infertile women population. Also, levothyroxine treatment followed by a re-evaluation of the ovarian reserve was not performed in this study.

\section{Conclusion}

Our study supports the inverse relationship between thyroid-stimulating hormone and ovarian reserve, and an increase in TSH from a cut-off point of $1.465 \mathrm{mIU} / \mathrm{L}$ in participants over 35 , is associated with a decrease in ovarian function. Larger prospective studies are needed to confirm these findings.

\section{Acknowledgements \\ The authors would like to thank the members of the Reproductive Health Research Center of Guilan University of Medical Sciences for their continual support.}

\section{Authors' contributions}

S.H.Sh., R.K., F.M., Z.Z.S. contributed to conception and study design, data collection; N.G.G., and Z.Ch. drafted the manuscript, which was revised by R.K.;
M.Gh., performed statistical analysis; all authors read and approved the final manuscript.

Funding

This work was supported by Guilan University of Medical Sciences.

Availability of data and materials

Not applicable.

\section{Declarations}

Ethics approval and consent to participate

Approval was obtained from the Ethics Committee of Guilan University of Medical Sciences (Approval ID: IR.GUMS.REC.1399.541) and informed consent was obtained from all patients before enrollment.

\section{Consent for publication}

Not applicable.

\section{Competing interests}

There was no conflict of interest.

\section{Author details}

${ }^{1}$ Reproductive Health Research Center, Department of Obstetrics \& Gynecology, Al-Zahra Hospital, School of Medicine, Guilan University of Medical Sciences, Namjoo Street, P.O.Box: 4144654839, Rasht, Iran. ${ }^{2}$ Mehr Fertility Research Center, Guilan University of Medical Sciences, Rasht, Iran. ${ }^{3}$ Vice-Chancellorship of Research and Technology, Guilan University of Medical Science, Rasht, Iran.

Received: 5 July 2021 Accepted: 19 September 2021

Published online: 01 October 2021

\section{References}

1. Jeppesen JV, Anderson RA, Kelsey TW, Christiansen SL, Kristensen SG, Jayaprakasan $\mathrm{K}$, et al. Which follicles make the most anti-Müllerian hormone in humans? Evidence for an abrupt decline in AMH production at the time of follicle selection. MHR Basic Sci Reprod Med. 2013;19(8):519-27.

2. Morin SJ, Patounakis G, Juneau CR, Neal SA, Scott RT Jr, Seli E. Diminished ovarian reserve and poor response to stimulation in patients<38years old: a quantitative but not qualitative reduction in performance. Hum Reprod. 2018;33(8):1489-98.

3. Aoki Y, Belin RM, Clickner R, Jeffries R, Phillips L, Mahaffey KR. Serum TSH and total T4 in the United States population and their association with participant characteristics: National Health and Nutrition Examination Survey (NHANES 1999-2002). Thyroid. 2007;17(12):1211-23.

4. Vissenberg R, Manders VD, Mastenbroek S, Fliers E, Afink GB, Ris-Stalpers $C$, et al. Pathophysiological aspects of thyroid hormone disorders/thyroid peroxidase autoantibodies and reproduction. Hum Reprod Update. 2015;21(3):378-87.

5. Zhang C, Wang X, Wang Z, Niu W, Zhu B, Xia G. Effect of different culture systems and 3,5, 3'-triiodothyronine/follicle-stimulating hormone on preantral follicle development in mice. PLoS One. 2013;8(4):e61947.

6. Stuckey BGA, Yeap D, Turner SR. Thyroxine replacement during superovulation for in vitro fertilization: a potential gap in management? Fertil Steril. 2010;93(7):2414-e1.

7. Colicchia M, Campagnolo L, Baldini E, Ulisse S, Valensise H, Moretti C. Molecular basis of thyrotropin and thyroid hormone action during implantation and early development. Hum Reprod Update. 2014;20(6):884-904.

8. Oki N, Matsuo H, Nakago S, Murakoshi H, Laoag-Fernandez JB, Maruo T. Effects of 3, 5, 3'-triiodothyronine on the invasive potential and the expression of integrins and matrix metalloproteinases in cultured early placental extravillous trophoblasts. J Clin Endocrinol Metab. 2004;89(10):5213-21. 
9. Michalakis KG, Mesen TB, Brayboy LM, Yu B, Richter KS, Levy M, et al. Subclinical elevations of thyroid-stimulating hormone and assisted reproductive technology outcomes. Fertil Steril. 2011;95(8):2634-7.

10. Kuroda K, Uchida T, Nagai S, Ozaki R, Yamaguchi T, Sato Y, et al. Elevated serum thyroid-stimulating hormone is associated with decreased anti-Müllerian hormone in infertile women of reproductive age. J Assist Reprod Genet. 2015;32(2):243-7.

11. Weghofer A, Barad DH, Darmon S, Kushnir VA, Gleicher N. What affects functional ovarian reserve, thyroid function or thyroid autoimmunity? Reprod Biol Endocrinol. 2016;14(1):1-6.

12. Akın EÖ, Aycan Z. Evaluation of the ovarian reserve in adolescents with Hashimoto's thyroiditis using serum anti-müllerian hormone levels. J Clin Res Pediatr Endocrinol. 2018;10(4):331.

13. Chen C-W, Huang Y-L, Tzeng C-R, Huang R-L, Chen C-H. Idiopathic low ovarian reserve is associated with more frequent positive thyroid peroxidase antibodies. Thyroid. 2017;27(9):1194-200.

14. Schoemaker J, Drexhage $H$, Hoek A. Premature ovarian failure and ovarian autoimmunity. Endocr Rev. 1997

15. Kim C-H, Ahn J-W, Kang SP, Kim S-H, Chae H-D, Kang B-M. Effect of levothyroxine treatment on in vitro fertilization and pregnancy outcome in infertile women with subclinical hypothyroidism undergoing in vitro fertilization/intracytoplasmic sperm injection. Fertil Steril. 2011;95(5):1650-4

16. Galey-Fontaine J, Cédrin-Durnerin I, Chaïbi R, Massin N, Hugues J-N. Age and ovarian reserve are distinct predictive factors of cycle outcome in low responders. Reprod Biomed Online. 2005;10(1):94-9.

17. Hvidman HW, Bentzen JG, Thuesen LL, Lauritsen MP, Forman JL, Loft A, et al. Infertile women below the age of 40 have similar anti-Müllerian hormone levels and antral follicle count compared with women of the same age with no history of infertility. Hum Reprod. 2016;31(5):1034-45.

18. Broekmans FJ, Knauff EAH, te Velde ER, Macklon NS, Fauser BC. Female reproductive ageing: current knowledge and future trends. Trends Endocrinol Metab. 2007;18(2):58-65.

19. Faddy MJ, Gosden RG, Gougeon A, Richardson SJ, Nelson JF. Accelerated disappearance of ovarian follicles in mid-life: implications for forecasting menopause. Hum Reprod. 1992;7(10):1342-6.
20. Gougeon A, Ecochard R, Thalabard JC. Age-related changes of the population of human ovarian follicles: increase in the disappearance rate of non-growing and early-growing follicles in aging women. Biol Reprod. 1994;50(3):653-63.

21. Merhi Z, Zapantis A, Berger DS, Jindal SK. Determining an anti-Mullerian hormone cutoff level to predict clinical pregnancy following in vitro fertilization in women with severely diminished ovarian reserve. J Assist Reprod Genet. 2013;30(10):1361-5.

22. Polyzos NP, Sakkas E, Vaiarelli A, Poppe K, Camus M, Tournaye H. Thyroid autoimmunity, hypothyroidism and ovarian reserve: a cross-sectional study of 5000 women based on age-specific AMH values. Hum Reprod. 2015;30(7):1690-6.

23. Korevaar TIM, Mínguez-Alarcón L, Messerlian C, de Poortere RA, Williams $\mathrm{PL}$, Broeren MA, et al. Association of thyroid function and autoimmunity with ovarian reserve in women seeking infertility care. Thyroid. 2018;28(10):1349-58.

24. Kucukler FK, Gorkem U, Simsek Y, Kocabas R, Guler S. Evaluation of ovarian reserve in women with overt or subclinical hypothyroidism. Arch Med Sci AMS. 2018;14(3):521.

25. Rao M, Wang H, Zhao S, Liu J, Wen Y, Wu Z, et al. Subclinical hypothyroidism is associated with lower ovarian reserve in women aged 35 years or older. Thyroid. 2020;30(1):95-105.

26. Kuroda M, Kuroda K, Segawa T, Noh JY, Yoshihara A, Ito K, et al. Levothyroxine supplementation improves serum anti-Müllerian hormone levels in infertile patients with Hashimoto's thyroiditis. J Obstet Gynaecol Res. 2018;44(4):739-46.

\section{Publisher's Note}

Springer Nature remains neutral with regard to jurisdictional claims in published maps and institutional affiliations.
Ready to submit your research? Choose BMC and benefit from:

- fast, convenient online submission

- thorough peer review by experienced researchers in your field

- rapid publication on acceptance

- support for research data, including large and complex data types

- gold Open Access which fosters wider collaboration and increased citations

- maximum visibility for your research: over $100 \mathrm{M}$ website views per year

At BMC, research is always in progress.

Learn more biomedcentral.com/submissions 